\title{
Antioxidants Aleviate Nicotine-Induced Platelet Aggregation in Cerebral Arterioles of Mice in Vivo
}

\author{
M. A. FAHIM ${ }^{1}$, A. NEMMAR ${ }^{1}$, S. SINGH ${ }^{1}$, M. Y. HASSAN ${ }^{2}$ \\ ${ }^{1}$ Department of Physiology, Faculty of Medicine, United Arab Emirates University, Al Ain, UAE, \\ ${ }^{2}$ Department of Pharmacology, Faculty of Medicine, United Arab Emirates University, Al Ain, UAE
}

Received November 10, 2010

Accepted March 25, 2011

On-line May 16, 2011

\section{Summary}

Experimental data on the effect of nicotine on cerebral microvessel thrombosis is lacking. Therefore, this study was carried out to elucidate the effects of nicotine on platelet aggregation in cerebral (pial) microcirculation of the mouse, and the possible protective effect of vitamins $C$ and $E$. Male TO mice were divided into six groups, and injected i.p. with saline as a control, nicotine $(1 \mathrm{mg} / \mathrm{kg})$, vitamin C alone $(100 \mathrm{mg} / \mathrm{kg})$, vitamin E alone $(100 \mathrm{mg} / \mathrm{kg})$, nicotine plus vitamin C or nicotine plus vitamin $E$, all for one week before the experiment. After one week, platelet aggregation in cerebral microvessels of these groups of mice were studied in vivo. The appearance of the first platelet aggregation and total blood flow stop in arterioles and venules were timed in seconds. In the animals treated with nicotine, venules did not show any alteration in the platelet aggregation time in comparison to the control animals. However, in arterioles platelet aggregation time was significantly accelerated $(p<0.001)$ in nicotine-treated animals as compared to controls. Both vitamins $\mathrm{C}$ and $\mathrm{E}$ prevented the shortening of arteriolar platelet aggregation time significantly $(p<0.001)$ when applied with nicotine but not alone. It can be concluded that nicotine enhances the susceptibility to thrombosis in the cerebral arterioles in vivo and that vitamins $\mathrm{C}$ and $\mathrm{E}$ have alleviating effect on nicotine-induced thrombotic events in mice pial microvessels.
\end{abstract}

\section{Key words}

Nicotine • Microcirculation • Thrombosis • Platelets

\section{Corresponding author}

M. A. Fahim, United Arab Emirates University, Faculty of Medicine and Health Sciences, Department of Physiology, P.O. Box 17666, Al Ain, UAE. Fax: +971 3 7671966. E-mail: m.fahim@uaeu.ac.ae
Tobacco smoke, a health hazard most widely associated with cancer, is also a significant independent risk factor for cardiovascular disease and a leading cause of structural and functional alterations of the cardiovascular system (Bernhard et al. 2003, Rahman and Laher 2007, Shireen et al. 2008).

Most clinical and experimental investigations on the pathophysiology of cigarette smoking have studied the effects of smoke as a whole, while a few studies focused on specific components of cigarette smoke, e.g. nicotine (Rubenstein et al. 2004). Nicotine exposure via cigarette smoking has been implicated in the pathogenesis of cardiovascular disorders like atherosclerosis and hypertension (Lindenblatt et al. 2007). Nicotine causes vasoconstriction and increased blood pressure (Lindenblatt et al. 2007). A drop in blood-flow velocity in humans, endothelial damage in rats, and inhibition of platelet aggregation in rabbit blood, have all been shown experimentally (Lindenblatt et al. 2007). Nicotine has been reported to upregulate the expression of various proteins such as basic fibroblast growth factor, tumor necrosis factor- $\alpha$ and plasminogen activator inhibitor- 1 (Lau et al. 2006). In addition, nicotine induces mononuclear leukocyte adhesion and expression of adhesion molecules such as vascular cell adhesion molecule-1 and intracellular adhesion molecule in endothelial cells (Albaugh et al. 2004).

Circulating platelets do not normally adhere to the endothelial cells of the vascular wall or aggregate, except when activated or when the endothelium is damaged. Delivery of blood to various organs and proper tissue perfusion are significant for normal tissue function. 
Development of thrombi in the circulatory system would result in reduced blood delivery and consequently, in tissue hypoxia/ischemia. Smoking is linked to thromboembolic events (Hioki et al. 2001), but a relationship between nicotine exposure and cerebral microvessel thrombosis has not been established.

Oxidative stress has been shown to be the major cause of atherosclerosis and smoking is considered to induce oxidative stress. Oxidative stress arises from an imbalance between the production of free radicals and physiological antioxidant capability. The supplementation with vitamin $\mathrm{C}$ and $\mathrm{E}$ has been reported to provide health benefits against cardiovascular diseases through its antioxidant activity, and the inhibition of platelet aggregation (Niki, 2004, Singh and Jialal 2006, Sesso et al. 2008, Violi et al. 2010).

Therefore, the aim of this study was to examine the influence of nicotine exposure on the in vivo platelet aggregation in cerebral, pial, microcirculation of mice, and to assess the possible protective effects of vitamin $\mathrm{C}$ and vitamin $\mathrm{E}$.

All animal treatment procedures met both the $\mathrm{NIH}$ and Institutional Animal Ethics Committee guidelines. Adult male mice, TO strain, weighing 30-35 g from a colony maintained in our animal house facility were used. Animals were group-housed in a temperature maintained $\left(22 \pm 2{ }^{\circ} \mathrm{C}\right)$ and a light/dark cycle $(12 / 12 \mathrm{~h})$ environment. They had access to standard pelleted diet and water ad libitum. Except for their intended treatment all animals were handled in the same manner.

Nicotine (Sigma) aqueous solution (40\%) in a dose of $1 \mathrm{mg} / \mathrm{kg}$ body weight was dissolved in normal saline and injected intraperitoneally (i.p) for one week every day. Normal saline (vehicle) was injected in the same manner to the control. Concurrently with the nicotine or saline treatment, animals were injected (i.p.) with antioxidants: vitamin $\mathrm{C}(100 \mathrm{mg} / \mathrm{kg}$ b.w./day), or vitamin $\mathrm{E}$ (100 mg/kg b.w./day) for the same week.

After the treatments, mice were anesthetized with urethane $(25 \%, 0.1 \mathrm{ml} / 10 \mathrm{~g}$ b.w., i.p) and trachea was intubated. Cerebral microvessels were exposed after performing craniotomy on the anesthetized mice on the left side of the head, with the aid of a microdrill and dura was carefully removed. The body temperature was stabilized at $37{ }^{\circ} \mathrm{C}$ with the help of an infrared lamp and monitored with a rectal thermoprobe (Physitemp Model RET-3). The preparation was kept moist with artificial cerebrospinal fluid (ACSF). Composition of the ACSF used was (mM): $\mathrm{NaCl} 124, \mathrm{KCl} 5, \mathrm{NaH}_{2} \mathrm{PO}_{4} 3, \mathrm{CaCl} 2.5$,
$\mathrm{MgSO}_{4}, 2.4, \mathrm{NaHCO}_{3}$ 23, and glucose 10; pH 7.3. Preparation showing any level of trauma to the vessel or brain tissue was discarded.

The closed circuit set up used consisted of a fluorescence microscope (Olympus, $\mathrm{BH}-2$ ), a video camera (JVC, TK-890E), a VHS-VCR (JVC, BR-S600E) and a television monitor (JVC, TM-1500PS). All microscopic observations utilized a fiber-optic light source and were made using a $4 \mathrm{x}$ objective lens and a $10 \mathrm{x}$ eye piece. Total magnification of the observed field, from the microscope stage to the television monitor was $\mathrm{x} 250$.

Sodium fluorescein $(2 \%, 0.1 \mathrm{ml} / 10 \mathrm{~g}$ b.w.) was injected via the tail vein. It was allowed to circulate in the body for 30 seconds before mercury light was switched on. The combination of mercury light exposure and fluorescein dye produces a free radical which injures the endothelium of the microvessel lumen. This in turn, causes platelets to adhere at the sites of endothelial damage and then aggregate. The fluorescence of aggregates was readily visible as they adhered to the damaged endothelium (Fig. 1). Platelet aggregates grow in size until complete vascular occlusion (Fig. 1). The time when the first observable aggregate appeared (time to first aggregate) and until full vascular occlusion (time to flow stop) in both venules and arterioles (Fig. 1) were measured in seconds. The time of aggregate growth was calculated as the difference between the time to flow stop and the time to first aggregate. Diameters before insult and after full vascular occlusion were measured in control and treated mice from video recordings and changes were calculated. All events were video-taped for analysis and measurement of microvessel diameter changes.

All data were analyzed with GraphPad Prism Version 4.01 for Windows software (Graphpad Software Inc., San Diego, CA). Data are expressed as means \pm S.D. Comparisons between groups were performed using the Mann-Whitney $\mathrm{U}$ test. A $p$ value $<0.05$ was considered to indicate statistical significance.

The effects of nicotine treatments on the time required for platelet aggregation and for full occlusion in pial microvessels are summarized in the Table 1. Our results show that in the animals treated with nicotine $(1 \mathrm{mg} / \mathrm{kg})$ one week before the experiment, venules did not show any alteration in the platelet aggregation timings in comparison to the control animals. But in arterioles platelet aggregation time was significantly accelerated $(\mathrm{p}<0.001)$ in nicotine treated animals. In both arterioles and venules, vascular diameter changes 
throughout the photochemical insult among both groups were within a very narrow range and no statistically significant differences were present (Table 1). Data on platelet aggregation revealed significant shorter times $(\mathrm{P}<0.001)$ for the appearance of the first aggregate in pial arterioles of the nicotine-treated group, thus indicating an increased susceptibility to thrombosis in nicotine-exposed animals. In contrast to arterioles, measured platelet aggregation parameters in venules were not significantly different in control and nicotine-exposed animals.

When vitamins $\mathrm{C}$ and $\mathrm{E}$ were injected alone, the time for the first observed platelet aggregation and for full occlusion in pial microvessels did not significantly change. However, when both vitamins were injected concurrently with nicotine, they reduced significantly $(p<0.001)$ the time required to initiate the thromboembolic platelet aggregation and the time for full occlusion in pial microvessels as compared with nicotinetreated mice (Table 1).

The present study revealed that nicotine treatment accelerated the time required for both the appearance of the first aggregate and the time for full occlusion in pial arterioles. Although both vitamins $\mathrm{C}$ and E when injected alone decreased the timing of the pial arteriols thrombotic events not significantly, but their concurrent injection along with nicotine indeed had a significant effect $(\mathrm{p}<0.001)$ when compared to nicotine treatment alone (Table 1).

The nicotine dose and the duration of the treatment was selected according to the excellent review (Matta and Elberger 2007) that explains the approaches which have been developed, strain-dependent differences, modes of nicotine administration, each resulting in elevated blood nicotine concentration.

The results of this study complement the data from previous studies in animals and humans. For example, reported data indicate that nicotine and cotinine exert direct effects on endothelial cells and smooth muscle cells, shifting them toward a pro-thrombotic state via induction of tissue factor expression (Massberg et al. 2002). These effects on cells of the vessel wall might explain, at least in part, the deleterious cardiovascular consequences of smoking. Platelet-dependent thrombin level is enhanced in smokers, even when not smoking, when compared with non-smokers and increases immediately after smoking. Increases in nicotine and cotinine levels caused by smoking induced a prothrombotic state in smokers via increased plateletdependent thrombogenesis (Hioki et al. 2001).
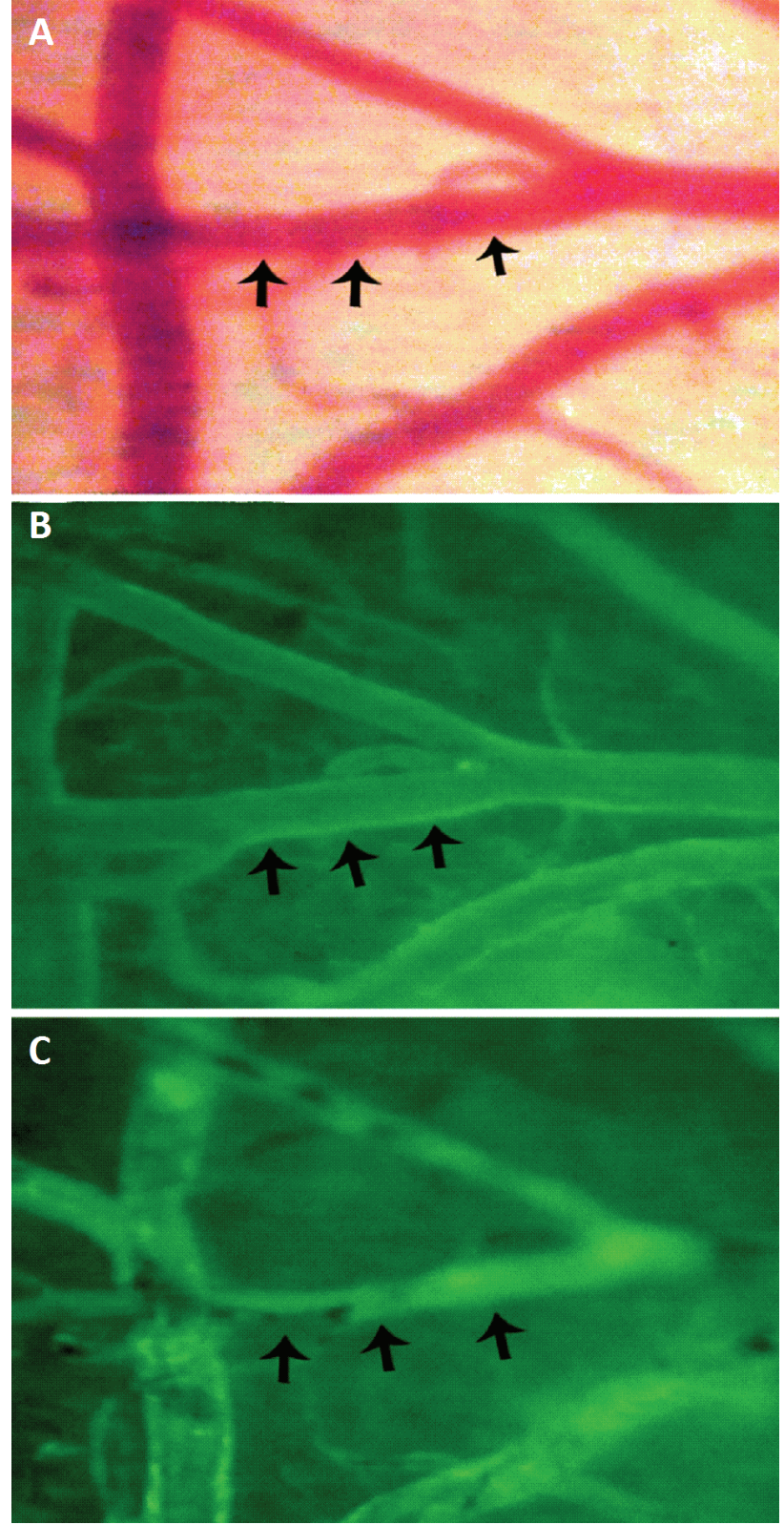

Fig. 1. Representative pictures of a field containing cerebral pial microvessels in control group before (A) and immediately after i.v. injection of fluoroscein (B), showing clearly the microvessels. Arrows indicate pial arteriole. As consequence of the photochemical reaction between fluorescein and continues illumination with mercury light, platelets start to aggregate and thrombus forms and grows in size until it causes a complete vascular occlusion (C). The differences in the occlusion times between the groups are indicated in Table 1.

Our data show that one week of antioxidants treatments revealed that both vitamins $C(100 \mathrm{mg} / \mathrm{kg})$ and $\mathrm{E}(100 \mathrm{mg} / \mathrm{kg})$ caused a significant reduction in platelet aggregation compared with control (Table 1, $P<0.001$ ). The doses of vitamin $\mathrm{C}$ and $\mathrm{E}$ used in the current study are comparable to the those reported by others in rats and mice (Komeima et al. 2006, Ming et al. 2006, Ocak et al. 2007). However, with respect to human studies, it has 
Table 1. Platelet aggregation timings and diameter changes in control vs nicotine and antioxidants treated animals.

\begin{tabular}{|c|c|c|c|c|c|c|}
\hline & $\begin{array}{l}\text { Control } \\
\text { (saline) }\end{array}$ & $\begin{array}{l}\text { Nicotine } \\
(1 \mathrm{mg} / \mathrm{ml})\end{array}$ & $\begin{array}{c}\text { Vitamin C } \\
\text { alone }\end{array}$ & $\begin{array}{c}\text { Vitamin } E \\
\text { alone }\end{array}$ & $\begin{array}{l}\text { Nicotine + } \\
\text { Vitamin C }\end{array}$ & $\begin{array}{l}\text { Nicotine + } \\
\text { Vitamin E }\end{array}$ \\
\hline $\begin{array}{l}\text { Weight of the } \\
\text { animals (g) }\end{array}$ & $33.7 \pm 1.1$ & $32.6 \pm 1.9$ & $31.6 \pm 1.5$ & $32.5 \pm 1.6$ & $31.9 \pm 1.5$ & $32.5 \pm 2.4$ \\
\hline \multicolumn{7}{|l|}{ Venules } \\
\hline $\begin{array}{l}\text { Time to first } \\
\text { aggregate }(s)\end{array}$ & $28.1 \pm 2.0$ & $25.4 \pm 1.6$ & $29.4 \pm 2.7$ & $27.4 \pm 2.2$ & $28.2 \pm 1.5$ & $26.9 \pm 2.1$ \\
\hline Lower $95 \%$ CI & 26.7 & 24.3 & 27.5 & 25.8 & 27.1 & 25.4 \\
\hline Upper $95 \% C I$ & 29.5 & 26.5 & 31.3 & 29.0 & 29.3 & 28.4 \\
\hline $\begin{array}{l}\text { Time to flow } \\
\text { stop }\end{array}$ & $167.1 \pm 31.7$ & $151.3 \pm 19.9$ & $174.0 \pm 27.6$ & $172.7 \pm 28.5$ & $159.6 \pm 20.1$ & $155.7 \pm 24.8$ \\
\hline Lower $95 \% C I$ & 144.4 & 137.0 & 154.2 & 152.3 & 145.2 & 138.0 \\
\hline Upper $95 \% C I$ & 189.8 & 165.6 & 193.8 & 193.1 & 174.0 & 173.4 \\
\hline \multicolumn{7}{|l|}{ Arterioles } \\
\hline $\begin{array}{l}\text { Time to first } \\
\text { aggregate (s) }\end{array}$ & $94.3 \pm 12.9$ & $54.7 \pm 9.9^{*}$ & $94.0 \pm 10.8$ & $91.4 \pm 8.1$ & $71.7 \pm 11.1^{*}$ & $70.5 \pm 12.0^{*}$ \\
\hline Lower $95 \%$ CI & 85.1 & 47.6 & 86.3 & 85.6 & 63.8 & 62.0 \\
\hline Upper $95 \%$ CI & 103.5 & 61.8 & 101.7 & 97.2 & 79.7 & 79.1 \\
\hline $\begin{array}{l}\text { Time to flow } \\
\text { stop }\end{array}$ & $201.1 \pm 23.8$ & $137.6 \pm 9.9$ & $196.1 \pm 14.2$ & $200.2 \pm 20.1$ & $155.1 \pm 21.3^{*}$ & $154.8 \pm 25.1^{*}$ \\
\hline Lower $95 \% C I$ & 184.0 & 130.5 & 185.9 & 185.8 & 139.9 & 136.8 \\
\hline Upper $95 \% C I$ & 218.0 & 144.7 & 206.3 & 214.6 & 170.3 & 172.8 \\
\hline \multicolumn{7}{|c|}{ Venules diameter $(\mu m)$} \\
\hline Initial diameter & $42.6 \pm 3.5$ & $41.0 \pm 4.4$ & $39.8 \pm 3.3$ & $41.1 \pm 5.0$ & $44.1 \pm 2.4$ & $43.2 \pm 2.4$ \\
\hline Lower $95 \% C I$ & 40.1 & 37.9 & 37.4 & 37.6 & 42.4 & 41.2 \\
\hline Upper $95 \%$ CI & 45.1 & 44.1 & 42.2 & 44.6 & 45.8 & 44.9 \\
\hline $\begin{array}{l}\text { Diameter after } \\
\text { the aggregation }\end{array}$ & $51.2 \pm 7.5$ & $51.9 \pm 11.9$ & $48.9 \pm 5.3$ & $52.7 \pm 7.5$ & $53.6 \pm 4.7$ & $52.5 \pm 4.4$ \\
\hline Lower $95 \%$ CI & 45.8 & 43.4 & 45.1 & 47.4 & 50.3 & 49.3 \\
\hline Upper $95 \% C I$ & 56.6 & 60.4 & 52.7 & 58.0 & 56.9 & 55.7 \\
\hline \multicolumn{7}{|c|}{ Arterioles diameter (um) } \\
\hline Initial diameter & $41.1 \pm 4.3$ & $37.8 \pm 2.0$ & $39.4 \pm 5.2$ & $39.9 \pm 3.8$ & $41.5 \pm 3.0$ & $41.7 \pm 2.8$ \\
\hline Lower $95 \% C I$ & 38.0 & 36.4 & 35.7 & 37.2 & 39.3 & 39.7 \\
\hline Upper $95 \%$ CI & 44.2 & 39.2 .1 & 43.1 & 42.6 & 43.7 & 43.7 \\
\hline $\begin{array}{l}\text { Diameter after } \\
\text { the aggregation }\end{array}$ & $50.3 \pm 9.9$ & $48.8 \pm 8.6$ & $49.9 \pm 7.4$ & $49.7 \pm 6.5$ & $50.1 \pm 4.7$ & $51.4 \pm 5.5$ \\
\hline Lower $95 \%$ CI & 43.2 & 42.7 & 44.6 & 45.1 & 46.8 & 47.4 \\
\hline Upper $95 \%$ CI & 57.4 & 55.0 & 55.2 & 54.4 & 53.5 & 55.4 \\
\hline
\end{tabular}

$* \mathrm{P}<0.001$, number of animals $\mathrm{n}=10$, values are means \pm standard deviation.

been reported that doses of vitamin $\mathrm{C}$ are generally tolerated up to a level of $2000 \mathrm{mg}$ /day (Standing Committee on the Scientific Evaluation of Dietary Reference Intakes 2000, Sesso et al. 2008). A dose of $400 \mathrm{IU} /$ day $(\sim 268 \mathrm{mg} /$ day $)$ vitamin $\mathrm{E}$ has been used in large-scale clinical trial for cancer prevention with cardiovascular disease as secondary endpoints (Lippman et al. 2005). Thus, compared to human studies, the doses of vitamins $\mathrm{E}$ and $\mathrm{C}$ in our study were relatively high.

Vitamin $\mathrm{E}$ is the principal lipid-soluble antioxidant in human plasma, and some studies indicate that it may provide cardiovascular protection (Violi et al. 2010). Oxidative stress has been considered to play a major role in the development of atherosclerosis. 
Consistent with this idea, numerous studies have shown an inverse association between atherosclerosis and antioxidant intake (Golestani et al. 2006, Guney et al. 2007, Demiralay et al. 2008, Chiu et al. 2009). The development of atherosclerosis and myocardial ischemiareperfusion injury; both of these phenomena are associated with platelet activation (Ulker et al. 2003). It has been reported that tissue-type plasminogen activator enhanced platelet adhesion, and co-administration of vitamin $\mathrm{E}$ further decreased platelet adhesion in a model of thrombosis (Hioki et al. 2001, Cirillo et al. 2006). Moreover, an inverse relationship between the intake of vitamin $\mathrm{C}$ and risk of an acute myocardial infarction was found in humans (Antoniades et al. 2003, Chiu et al. 2009). Non-toxic doses of vitamin $E$ in treated rats can upregulate SOD activity, but cumulative effect of the same doses can lead to the attenuation of SOD activity and hence antioxidant defense (Golestani et al. 2006). Moreover, vitamin E treatments significantly reduced the rate of nicotine-induced hippocampal neural cell apoptosis (Demiralay et al. 2008).

In animal models of endothelial dysfunction, vitamin $\mathrm{E}$ improved the activity of endothelium-derived nitric oxide, in part due to the inhibition of protein kinase C (PKC) stimulation (Freedman and Keaney Jr. 2001). This activity of vitamin E was examined in platelets, and vitamin $\mathrm{E}$ inhibited platelet aggregation in part through a mechanism that involves PKC (Freedman and Keaney Jr. 2001).

It can be concluded that one week exposure to nicotine causes prothrombotic events in the cerebral arterioles, and that the antioxidant vitamins $\mathrm{C}$ and $\mathrm{E}$ alleviate these effects. Further experiments are needed to investigate the mechanism underlying the observed effects.

\section{Conflict of Interest}

There is no conflict of interest.

\section{Acknowledgements}

This work was financially supported by a grant from the Research Affairs Office at the UAE University. The authors wish to thank Mr Subramanian Dhanasekaran for his technical help.

\section{References}

ALBAUGH G, BELlAVANCE E, STRANDE L, HEINBURGER S, HEWITT CW, ALEXANDER JB: Nicotine induces mononuclear leukocyte adhesion and expression of adhesion molecules, VCAM and ICAM, in endothelial cells in vitro. Ann Vasc Surg 18: 302-307, 2004.

ANTONIADES C, TOUSOULIS D, TENTOLOURIS C, TOUTOUZA M, MARINOU K, GOUMAS G, TSIOUFIS C, TOUTOUZAS P, STEFANADIS C: Effects of antioxidant vitamins C and E on endothelial function and thrombosis/fibrinolysis system in smokers. Thromb Haemost 89: 990-995, 2003.

BERNHARD D, PFISTER G, HUCK CW, KIND M, SALVENMOSER W, BONN GK, WICK G: Disruption of vascular endothelial homeostasis by tobacco smoke: impact on atherosclerosis. FASEB J 17: 2302-2304, 2003.

CHIU YW, CHUANG HY, HUANG MC, WU MT, LIU HW, HUANG CT: Comparison of plasma antioxidant levels and related metabolic parameters between smokers and non-smokers. Kaohsiung J Med Sci 25: 423-430, 2009.

CIRILlO P, DE ROSA S, PACILEO M, GARGIULO A, LEONARDI A, ANGRI V, FORMISANO S, CHIARIELLO M: Nicotine induces tissue factor expression in cultured endothelial and smooth muscle cells. $J$ Thromb Haemost 4: 453-458, 2006.

DEMIRALAY R, GURSAN N, ERDEM H: The effects of erdosteine, N-acetylcysteine, and vitamin E on nicotineinduced apoptosis of hippocampal neural cells. J Cell Biochem 104: 1740-1746, 2008.

FREEDMAN JE, KEANEY JF: Vitamin E inhibition of platelet aggregation is independent of antioxidant activity. J Nutr 131: 374S-377S, 2001.

GOLESTANI A, RASTEGAR R, SHARIFTABRIZI A, KHAGHANI S, PAYABVASH SM, SALMASI AH, DEHPOUR AR, PASALAR P: Paradoxical dose- and time-dependent regulation of superoxide dismutase and antioxidant capacity by vitamin E in rat. Clin Chim Acta 365: 153-159, 2006.

GUNEY M, ORAL B, DEMIRIN H, KARAHAN N, MUNGAN T, DELIBAS N: Protective effects of vitamins C and E against endometrial damage and oxidative stress in fluoride intoxication. Clin Exp Pharmacol Physiol 34: 467-474, 2007. 
HIOKI H, AOKI N, KAWANO K, HOMORI M, HASUMURA Y, YASUMURA T, MAKI A, YOSHINO H, YANAGISAWA A, ISHIKAWA K: Acute effects of cigarette smoking on platelet-dependent thrombin generation. Eur Heart $J$ 22: 56-61, 2001.

KOMEIMA K, ROGERS BS, LU L, CAMPOCHIARO PA: Antioxidants reduce cone cell death in a model of retinitis pigmentosa. Proc Natl Acad Sci USA 103: 11300-11305, 2006.

LAU PP, LI L, MERCHED AJ, ZHANG AL, KO KW, CHAN L: Nicotine induces proinflammatory responses in macrophages and the aorta leading to acceleration of atherosclerosis in low-density lipoprotein receptor(-/-) mice. Arterioscler Thromb Vasc Biol 26: 143-149, 2006.

LINDENBLATT N, PLATZ U, HAMEISTER J, KLAR E, MENGER MD, VOLLMAR B: Distinct effects of acute and chronic nicotine application on microvascular thrombus formation and endothelial function in male and female mice. Langenbecks Arch Surg 392: 285-295, 2007.

LIPPMAN SM, GOODMAN PJ, KLEIN EA, PARNES HL, THOMPSON IM, KRISTAL AR, SANTELLA RM, PROBSTFIELD JL, MOINPOUR CM, ALBANES D, TAYLOR PR, MINASIAN, LM, HOQUE A, THOMAS SM, CROWLEY JJ, GAZIANO JM, STANFORD JL, COOK ED, FLESHNER NE, LIEBER MM, WALTHER PJ, KHURI FR, KARP DD, SCHWARTZ GG, FORD LG, COLTMAN CA: Designing the selenium and vitamin E cancer prevention trial (SELECT). J Natl Cancer Inst 97: 94-102, 2005.

MASSBERG S, BRAND K, GRUNER S, PAGE S, MULLER E, MULLER I, BERGMEIER W, RICHTER T, LORENZ M, KONRAD I, NIESWANDT B, GAWAZ M: A critical role of platelet adhesion in the initiation of atherosclerotic lesion formation. J Exp Med 196: 887-896, 2002.

MATTA SG, ELBERGER AJ: Combined exposure to nicotine and ethanol throughout full gestation results in enhanced acquisition of nicotine self-administration in young adult rat offspring. Psychopharmacology (Berl) 193: 199213, 2007.

MING Z, FAN YJ, YANG X, LAUTT WW: Synergistic protection by S-adenosylmethionine with vitamins C and E on liver injury induced by thioacetamide in rats. Free Radic Biol Med 40: 617-624, 2006.

NIKI E: Antioxidants and atherosclerosis. Biochem Soc Trans 32: 156-159, 2004.

OCAK S, GORUR S, HAKVERDI S, CELIK S, ERDOGAN S: Protective effects of caffeic acid phenethyl ester, vitamin $\mathrm{C}$, vitamin $\mathrm{E}$ and $\mathrm{N}$-acetylcysteine on vancomycin-induced nephrotoxicity in rats. Basic Clin Pharmacol Toxicol 100: 328-333, 2007.

RAHMAN MM, LAHER I: Structural and functional alteration of blood vessels caused by cigarette smoking: an overview of molecular mechanisms. Curr Vasc Pharmacol 5: 276-292, 2007.

RUBENSTEIN D, JESTY J, BLUESTEIN D: Differences between mainstream and sidestream cigarette smoke extracts and nicotine in the activation of platelets under static and flow conditions. Circulation 109: 78-83, 2004.

SESSO HD, BURING JE, CHRISTEN WG, KURTH T, BELANGER C, MACFADYEN J, BUBES V, MANSON JE, GLYNN RJ, GAZIANO JM: Vitamins $\mathrm{E}$ and $\mathrm{C}$ in the prevention of cardiovascular disease in men: the Physicians' Health Study II randomized controlled trial. JAMA 300: 2123-2133, 2008.

SHIREEN KF, PACE RD, MAHBOOB M, KHAN AT: Effects of dietary vitamin E, C and soybean oil supplementation on antioxidant enzyme activities in liver and muscles of rats. Food Chem Toxicol 46: 32903294, 2008.

SINGH U, JIALAL I: Oxidative stress and atherosclerosis. Pathophysiology 13: 129-142, 2006.

STANDING COMMITTEE ON THE SCIENTIFIC EVALUATION OF DIETARY REFERENCE INTAKES, FOOD AND NUTRITION BOARD: Dietary Reference Intakes for Vitamin C, Vitamin E. Selenium, and Betacarotene, and Other Carotenoids. National Academy Press, Washington, DC, 2000.

ULKER S, MCKEOWN PP, BAYRAKTUTAN U: Vitamins reverse endothelial dysfunction through regulation of eNOS and NAD(P)H oxidase activities. Hypertension 41: 534-539, 2003.

VIOLI F, PIGNATELLI P, BASILI S: Nutrition, supplements, and vitamins in platelet function and bleeding. Circulation 121: 1033-1044, 2010. 